\title{
ROLE OF HUMAN RESOURCE MANAGEMENT IN EMPLOYEES
}

\section{PERFORMANCE AND SATISFACTION OF SELECTED}

\section{HOSPITALS IN INDIA - A STRATEGIC PERSPECTIVE}

\author{
VINAY OJHA ${ }^{1} \&$ GYANESH KUMAR SINHA ${ }^{2}$ \\ ${ }^{1}$ Research Scholar, G. D Goenka University, Gurgaon, India \\ ${ }^{2}$ Associate Professor, G. D Goenka University, Gurgaon, India
}

\begin{abstract}
The research paper aims to discuss the concept of employee satisfaction, factors or determinants of employee satisfaction, and benefits or outcomes of employee satisfaction. The study is research in nature. Employee satisfaction is important for an organization as the overall performance of an organization depends on the satisfaction level of its employees. Satisfied employees do their work efficiently, and provide better customer services, which in turn leads to increased productivity, high level of quality, and optimum utilization of organizational resources. The main objective of the research was to measure the perceived effectiveness of HRM practices in the healthcare sector and to measure the impact of HRM practices on the performance of employees in the healthcare sector and to compare the HRM practices of the public and private hospitals. There are very few studies where a researcher has measured the HRM practices of the healthcare sector. Researchers have measured the impact of HRM practices on various aspects of the organizations but not suggested the innovative methods based on the findings of the research to improve the effectiveness of the companies. It was found out using various tests that how HR affects the employee's performance directly in the hospitals.
\end{abstract}

KEYWORDS: Employee Satisfaction, HRM Practices, Healthcare Sector \& Employee's Performance

Received: Aug 18, 2018; Accepted: Sep 10, 2018; Published: Oct 31, 2018; Paper Id.: IJHRMRDEC20184

\section{INTRODUCTION}

Human Resource Management involved the creation of a formal system in order to manage people in an organization. Scott et al., (1977) stated that Human Resource is a branch of Management that is responsible for the relationship between management and employee, employee to employee, along with the development of a person and group. The aim is to have individual development, desirable working environment and relationship between employers and employee and, employee and employee. According to Fisher (1977), Human Resource Management included all decision and practices that influence employees and employers. The management's decision affects employee planning, staff appraisals, training, staff development, safety, and compensation.

\section{THE RELATIONSHIP BETWEEN HRM PRACTICES AND JOB SATISFACTION, JOB PERFORMANCE AND INTENTION TO QUIT}

Steijin, (2002) found out a positive relationship while studying the connection between HRM practice and job satisfaction. The research is conducted on the employees of Dutch Public to examine benefits and reward 
system. Bradley, (2004) conducted a study where he concluded that job satisfaction is positively connected with the correct HRM practices. Petrescu and Simmons, (2008) confirmed the positive correlation between HRM practice and job satisfaction.

Turkyilmaz et al., (2011) stated that job satisfaction is mainly related to the benefits and awards. Mudor and Tooksoon, (2011) and Maurer (2001) also had a similar finding. They had linked up benefits and reward as the main reason for job satisfaction. Jun, Cai, and Shin, (2006) and Saks (1996) stated that training programmes were responsible for job satisfaction because they would lead to the growth of an employee and enhance their knowledge.

Just as customers were retained by customer satisfaction, healthcare employees were retained in the field by job satisfaction as suggested by Shaver et al., (2003). A study is conducted in Lebanon amongst nursing directors by El-Jardali Merhi Jamal Dumit Mouro (2009) found that rewards and benefits had a positive influence on job satisfaction. An issue related to high performance is studied in 20 nursing homes in the USA by Eaton. She found out that after the remodeling of HRM, a quality outcome of nursing homes improved but business performance is affected in the healthcare sector.

\section{REVIEW OF LITERATURE}

There is a huge literature available on HRM practices. Azeez (2017) studied the relationship between employee retention and HRM practices. the study was conceptual in nature and based on the past literature. Jouda et al. (2016) studied the HRM practices of Islamic University situated in Gaza in Palestine. Researchers have also measured the relationship between HRM practices and the performance of the employees. The research was based on the primary data collected from the 115 faculty members and the administrative staff members of the Islamic university. Bondarouk (2016) conducted a study to examine the impact of information technology on human resource management. The researcher stated that information technology is the vital component of the organizations and Human resource management in any organization get affected by the usage of information technology. Terera and Nagirande (2014) conducted a study to highlight the HR practices which lead to employee retention in any organization. Research revealed that the HR practices which have a significant impact on the employee retention were mainly; training \& development, salary, rewards, leadership, and the performance appraisal etc. Nalla and Varalaxmi (2014) studied the HRM practices in the retail sector, specifically in the organized retail sector in India. Scheible et al. (2013) examined the impact of HR practices on organizational commitment. Researchers also studied that how the perception of the employees towards the HR practices affect their entrenchment. Andreeva and Kianto (2012) measured the importance of knowledge management practices in an organization and its impact on the economic performance of an organization. Hussain and Ahmad (2012) made an extensive review of all the past studies available on human resource management practices. Waiganjo et. al. (2011) conducted a study to examine the relationship between strategic human resource management and the performance of the organizations. Ruel, Bondarouk, and Velde (2007) studied the role of e-HRM in increasing the effectiveness of HRM practices.

There are many other literature reviews which were studied carefully and analyzed to find out the scope of our study.

\section{GAPS IN REVIEW OF LITERATURE}

Following are the gaps found during the review of past literature on the HRM practices and its relationship with the various employees' outcomes and organizational outcomes: 
- There are very few studies where a researcher has measured the HRM practices of the healthcare sector.

- $\quad$ There are few studies available on HRM practices in the Indian context.

- Comparative studies of HRM practices on the public and private sector are limited.

- Researchers have measured the impact of HRM practices on various aspects of the organizations but not suggested the innovative methods based on the findings of the research to improve the effectiveness of the companies.

\section{OBJECTIVES OF THE STUDY}

Current research aims to achieve the following objectives and sub-objectives:

The main objective of the study is to measure the role of Human resource management practices of hospitals in the performance of their employees.

The sub-objectives are as follows:

- To measure the perceived effectiveness of HRM practices in the healthcare sector.

- $\quad$ To measure the impact of HRM practices on the performance of employees in the healthcare sector.

- To measure the mediating impact of demographic variables on the relationship between the effectiveness of HRM practices and performance of employees in hospitals.

- $\quad$ To compare the HRM practices of public and private hospitals.

- To suggest the measures for the improvement in the HRM practices in the healthcare sector.

\section{TYPES OF DATA}

In this study, both the secondary data and primary data has been used by the researcher. Secondary data has been used for the sampling purpose, extracting literature, current scenario of the health care sector of India, the number of healthcare workers. Here the secondary data related to a number of healthcare employees working in private and public hospitals of four selected metro cities, number of beds per hospitals has been collected.

The total number of healthcare employees working in the position of Doctors, Nurses and Paramedics and other staff members in India, was 4713061 till March 2016 as per the Report of Healthcare Industries, (www.ibef.org). The confidence interval was taken 5 percent and the level of confidence was taken as 99 percent. Sample size which is calculated with the help of this formula for the current study was 666 which were round of to 660; total 660 questionnaires were distributed equally in both the public and private hospitals of four metro cities of India namely; Mumbai, Kolkata, Delhi, and Chennai, for the collection of data. A total number of questionnaires which were duly completed filled up by the healthcare employee was used by the researcher for final data analysis.

The major criteria for selection of the hospitals for the study were the number of beds in the hospitals, all the hospitals which are having over 100 beds have been considered for the sampling scheme. There are total twenty private and public sector hospitals from four metro cities have been selected where the bed capacity is over 100 beds, out of that ten public and ten private hospitals have been selected by the researcher on random sampling method. 


\section{STATISTICAL METHODS FOR DATA ANALYSIS}

This section includes all the statistical methods used by the researcher for the analysis of primary and secondary data. As per the nature of the data, or variables, different tests have been applied to present the data in simple, understandable form and in a meaningful manner. Some of the statistical tests have been used to test the null hypothesis framed on the basis of the review of literature in order to accomplish the objectives of the study. Various statistical methods used by the researcher are mainly; t-test, Levene's test, Anova, chi-square test, and descriptive analysis.

\section{FINDINGS OF THE CURRENT RESEARCH}

A researcher has collected the data from 660 healthcare workers working in private and public hospitals of the Metro cities of India, with an aim to measure the effectiveness of HRM practices of the healthcare sector and its impact on job performance. Following are the main findings of the study:

- Demographic profile of the healthcare workers depicts that majority of the healthcare workers who have participated in the survey during current study were female workers, from an age group of 21 to 30 years, having Nursing degree, working on the position of Nurse in the hospitals from last 1 to 5 years, and earning an annual income between 1.5 lakh to 2.5 lakh. Researcher has taken an equal proportion of the health care workers from the private and public hospitals of metro cities of India and majority of the healthcare workers who have participated in the survey were working in the hospitals where the total strength of the healthcare workers was 301 to 400 and was having a bed capacity of 301 to 400 beds.

\section{- HRM PRACTICES AND EMPLOYEES' PERFORMANCE}

This section comprises the analysis to identify the relationship between the effectiveness of HRM practices of the hospitals and the performance of healthcare employees.

\section{Objective 1}

To Measure the Impact of HRM Practices on the Performance of Employees in the Healthcare Sector Table 1: Overall Performance of Healthcare Employees

\begin{tabular}{|c|c|c|c|c|c|}
\hline & \multicolumn{4}{|c|}{ Number|Percentage|Valid PercentageCumulative Percentage } \\
\hline \multirow{6}{*}{ Valid } & At learning stage & 29 & 4.4 & 4.4 & 4.4 \\
\hline & Average & 71 & 10.8 & 10.8 & 15.2 \\
\hline & Good & 164 & 24.8 & 24.8 & 40.0 \\
\hline & Very Good & 212 & 32.1 & 32.1 & 72.1 \\
\hline & Excellent & 184 & 27.9 & 27.9 & 100.0 \\
\hline & Total & 660 & 100.0 & 100.0 & \\
\hline
\end{tabular}

Interpretation: Table 1 shows the performance of healthcare employees, which infer that 32.1 percent of the employees have given an opinion that their overall performance was very good, 27.9 percent of the healthcare employees have an opinion that their overall performance was excellent, while only 4.4 percent of the healthcare employees perceived that their overall performance was only at learning stage only. 
Table 2: Accomplishment of Targets on Given Time

\begin{tabular}{|c|c|c|c|c|c|}
\hline & & Number & Percentag & Valid Percentage & Cumulative Percentage \\
\hline \multirow{6}{*}{ Valid } & Never & 55 & 8.3 & 8.3 & 8.3 \\
\hline & Rarely & 78 & 11.8 & 11.8 & 20.2 \\
\hline & Sometimes & 144 & 21.8 & 21.8 & 42.0 \\
\hline & Many times & 295 & 44.7 & 44.7 & 86.7 \\
\hline & Always & 88 & 13.3 & 13.3 & 100.0 \\
\hline & Total & 660 & 100.0 & 100.0 & \\
\hline
\end{tabular}

Interpretation: Table 2 shows the performance of healthcare employees, which infer that 44.7 percent of the employees have given an opinion that they have accomplished their targets in given time period, many times, 21.8 percent of the healthcare employees have an opinion that they have timely accomplished their targets only sometimes, while only 8.3 percent of the healthcare employees perceived that they have never accomplished their targets on time.

Table 3: Accomplishment of Targets

\begin{tabular}{|c|l|c|c|c|c|}
\hline \multicolumn{2}{|c|}{} & Number & Percentage & Valid Percentage & Cumulative Percentage \\
\hline \multirow{5}{*}{ Valid } & Never & 34 & 5.2 & 5.2 & 5.2 \\
\cline { 2 - 6 } & Rarely & 87 & 13.2 & 13.2 & 18.3 \\
\cline { 2 - 6 } & Sometimes & 186 & 28.2 & 28.2 & 46.5 \\
\cline { 2 - 6 } & Many times & 131 & 19.8 & 19.8 & 66.4 \\
\cline { 2 - 6 } & Always & 222 & 33.6 & 33.6 & 100.0 \\
\cline { 2 - 6 } & Total & $\mathbf{6 6 0}$ & $\mathbf{1 0 0 . 0}$ & $\mathbf{1 0 0 . 0}$ & \\
\hline
\end{tabular}

Interpretation: Table 3 shows the performance of healthcare employees, which infer that 33.6 percent of the employees have given an opinion that they always accomplish their targets, 28.2 percent of the healthcare employees have an opinion that they have accomplished their targets only sometimes, while only 5.2 percent of the healthcare employees perceived that they have never accomplished their targets.

Hypothesis 2: There is no significant relationship between the HRM practices and the performance of employees in health care sector.

Hypothesis 2.1: There is no significant relationship between performance appraisal system and the performance of employees in healthcare sector.

Hypothesis 2.2: There is no significant relationship between training \& development and the performance of employees in healthcare sector.

Hypothesis 2.3: There is no significant relationship between career advancement \& planning and the performance of employees in healthcare sector.

Hypothesis 2.4: There is no significant relationship between employee welfare \& compensation and the performance of employees in healthcare sector.

Hypothesis 2.5: There is no significant relationship between work-life balance policies and the performance of employees in healthcare sector.

A researcher has measured the impact of effective HRM practices on the performance of employees using step wise regression analysis. A researcher has used the following regression equation:

$$
\mathbf{X}=\alpha+\beta_{1} Y_{1}+\beta_{2} Y_{2}+\beta_{3} Y_{3}+\beta_{4} Y_{4}+\beta_{5} Y_{5}+\mathcal{C}
$$


Where; $\alpha$, is the constant term, $\beta_{1}, \beta_{2}, \beta_{3}, \beta_{4}$, and $\beta_{5}$, is the value of regression coefficients for the independent variables, $\delta$ denotes the error term, $X$ is the dependent variable i. e. Employees' Performance and $Y_{1}, Y_{2}, Y_{3}, Y_{4}$, and $Y_{5}$, are the independent variables i. e. Performance appraisal, Training \& development, Career advancement $\&$ planning, Employee welfare \& compensation and Work-life balance policies.

\section{Objective 2}

\section{To Measure the Perceived Effectiveness of HRM Practices in the Healthcare Sector}

It was found that healthcare employees perceive career advancement and planning opportunities very effective and the training \& development opportunities of hospitals as ineffective or less effective.

Results of t-test signified that there is a difference in the perception of the healthcare employees towards the effectiveness of the all the HRM practices namely; Performance Appraisal, Training \& Development, Employee Welfare, and Compensation, Career Advancement and Planning and Work-Life Balance. Even the overall perceived effectiveness of the HRM practices of the hospitals was found to be significantly different among healthcare employees. Hence, the null hypothesis got rejected and it can be inferred that the perception of the healthcare employees towards the effectiveness of HRM practices in the healthcare sector, were significantly different.

\section{Objective 3}

\section{To Measure the Impact of HRM Practices on the Performance of Employees in the Healthcare Sector}

It was found that there is a positive but low degree of correlation between Overall Performance of Healthcare employees and the perceived effectiveness of HRM practices namely; Work Life Balance, Employee Welfare and Compensation, Training \& Development, Career Advancement, and Planning, and Performance Appraisal.

It was found that the perceived effectiveness of HRM practices has a positive relation with the Overall Performance of Healthcare employees.

Work-Life Balance, and Career Advancement and Planning were found to have an insignificant relation with the performance of employees. Hence, it can be said that the perceived effectiveness of HRM practices, was found to be a significant predictor of the Overall Performance of Healthcare employees in healthcare sector

It was found that there is a positive but low degree of correlation between Performance of Healthcare employees based on their accomplishment of targets on time and the perceived effectiveness of HRM practices namely; Work Life Balance, Employee Welfare and Compensation, Training \& Development, Career Advancement, and Planning, and Performance Appraisal.

\section{Objective 4}

To Measure the Mediating Impact of Demographic Variables on the Relationship between the Effectiveness of HRM Practices and Performance of Employees in Hospitals

- Researcher has also measured the mediating effect of demographic variables on the relationship between effectiveness of HRM practices and performance of employees in hospitals and found that there is a positive but low degree of correlation between overall Performance of Healthcare employees and the perceived effectiveness of HRM practices namely; Work Life Balance, Employee Welfare and Compensation, Training \& Development, 
Career Advancement and Planning, and Performance Appraisal.

- It was found that the perceived effectiveness of HRM practices, was found to be positively and significantly related to the Overall Performance of Healthcare employees. Hence, it can be said that the perceived effectiveness of HRM practices, was found to be a significant predictor of the Overall Performance of Healthcare employees in the healthcare sector.

- Demographic variables and overall performance of the healthcare employees were found to have an insignificant relationship with the overall performance of the healthcare employees. Perceived effectiveness towards the HRM practices was found to have a positive and significant relationship with the overall performance of the healthcare employees. Hence, it can be said that the demographic variables namely; age, gender, job tenure, annual income, and designation were found to be insignificant mediating variables while the independent variable was found to be a significant predictor. TheNull hypothesis which states that there is no significant mediating effect of demographic variables on the relationship between the effectiveness of HRM practices and performance of employees in hospitals.

\section{Objective 5}

\section{To Compare the HRM Practices of Public and Private Hospitals}

- It was found that employees have an opinion that the HRM practices of public hospitals are more effective than private hospitals in metro cities of India. Value of t-test is found to be significant at one percent level of significance which leads to rejection of null hypothesis and it can be said there is a significant perceived effectiveness of HRM practices of the public and private hospitals.

- It was found that employees have an opinion that the performance appraisal in public hospitals is more effective than private hospitals in metro cities of India. Value of t-test is found to be significant at one percent level of significance which leads to rejection of null hypothesis and it can be said there is a significant in the perceived effectiveness of performance appraisal practices of the public and private hospitals.

- It was found that employees have an opinion that the training and development practices of public hospitals are more effective than private hospitals in metro cities of India. Value of t-test is found to be significant at one percent level of significance which leads to rejection of null hypothesis and it can be said there is a significant in the perceived effectiveness of Training \& Development practices of the public and private hospitals.

- It was found that employees have an opinion that the Career Advancement andPlanning practices of public hospitals is more effective than private hospitals in metro cities of India. Value of t-test is found to be significant at one percent level of significance which leads to rejection of null hypothesis and it can be said there is a significant difference in the perceived effectiveness of Career Advancement and Planning practices of the public and private hospitals.

- It was found that employees have an opinion that the Employee Welfare and Compensation practices of public hospitals are more effective than private hospitals in metro cities of India. Value of t-test is found to be significant at one percent level of significance which leads to rejection of null hypothesis and it can be said there is a significant difference in the perceived effectiveness of Employee Welfare and Compensation practices of the 
public and private hospitals.

- It was found that employees have an opinion that the Work-Life Balance practices of public hospitals are more effective than private hospitals in metro cities of India. Value of $t$-test is found to be significant at one percent level of significance which leads to rejection of null hypothesis and it can be said there is a significant difference in the perceived effectiveness of Work-Life Balance practices of the public and private hospitals.

\section{SUGGESTIONS OR RECOMMENDATIONS}

Following recommendations or suggestions have been given based on the key findings of the data analysis and literature review:

- Working hours should be fixed so as to establish proper family work balance. This can be taken a step further by offering flexible working hours.

- In view of the odd working hours of the employees, the proper facility should be provided to take care of their food and sanitation needs along with pickup and drop facilities for the employees, especially ladies who work in night shift or have to attend patients at odd hours due to some medical emergency.

- Another aspect is to sensitize the male staff through proper training so that they behave properly with the female staff. Female staff should have the feeling of being safe \& secure in the premises irrespective of the working timings.

- Hospital also employs a number of contractual workers who might be a security threat especially for female workers in absence of proper background checks and police verification. Attention needs to be paid in this regard apart from issuing proper I Cards.

- Hospital premises should be under constant CCTV surveillance in order to keep a check on mischief makers and anti-social elements.

- Suitable precautionary steps and SOP for treatment should be established so as to ensure the healthcare workers are safeguarded against any infection from the communicable disease infected patients

- Medicine stock \& diagnostic tools should be available as per requirement so that the proper treatment can be given to patients so that there are no acrimonious exchanges between the patient's family members and the staff.

- Proper security along with legal safeguards should be provided to all the staff to prevent any untoward incident between the patient's caretakers and hospital staff.

- As healthcare service is a highly demanding job exerting both physical and emotional pressured on the service providers it would be worthwhile to provide for regular training and counseling sessions to the staff.

- Often there are reports, especially in case of private hospitals that the medical staff is given revenue targets which compel them to unnecessarily retain patients at the hospital and also recommend tests which are not required. This needs to be checked so as the staff is not emotionally bogged down, being compelled to take the wrong line of treatment consciously under revenue pressure. 
It can be concluded from the study that the healthcare employees have different perception towards the effectiveness of the HRM practices namely; Performance appraisal, Training \& development, Career advancement \& planning, Employee welfare \& compensation, and Work-life balance policies. The performance of the healthcare employees was found to be above average in hospitals. From the comparison of the public and private hospitals of the metro cities of India, it was found that the HRM practices of the public hospitals are more effective than the private hospitals and there is a significant difference in the perceived effectiveness of the public and private hospitals. Further, the study showed that the perceived effectiveness of the HRM practices was found to have a significant impact on the overall performance of healthcare employees, while demographic attributes of the healthcare employees were found to have an insignificant mediating effect on the relationship between perceived effectiveness and overall performance of healthcare employees.

\section{LIMITATIONS}

A current study is based on the primary data hence; it suffers from all the limitations which are related to the primary data collection such as; negligence on the part of respondents, the disinterest of the respondents in filing the questionnaire, inconsistency or biased opinions of the respondents etc. Apart from this, the following are the major limitations of the study.

- The study has a geographical limitation as it is conducted on the healthcare employees working in the hospitals of metro cities of India only. Hence, the results of the study cannot be generalized to whole India or even urban areas itself.

- A researcher has taken a sample of 660 healthcare workers which is very small if we compare it with the total number of healthcare workers.

- A researcher has selected the hospitals whose bed capacity is over 100 , hence the results of the study will not be applicable to the small hospitals or nursing homes.

- Respondents of the study were chosen either nurses, paramedics or the ward boys etc. while in big hospitals the administrative staff also plays an important role in providing healthcare services and significantly influence the experience of the patients as after or before getting treatment patients to need to contact these staff members. Hence, it was important to measure the job satisfaction and motivation of these staff members also.

\section{REFERENCES}

1. Alba CoutoFalcãoScheible, AntônioVirgílioBittencourt Bastos, (2013), "An Examination of Human Resource Management Practices' Influence on Organizational Commitment and Entrenchment”, Influence on Organizational Commitment and Entrenchment, BAR, Rio de Janeiro, 10 (1), pp. 57-76.

2. Alusa Kennedy and Kariuki Anne, (2015), "Human Resource Management Practices, Employee Outcome and Performance of Coffee Research Foundation, Kenya”, European Journal of Business and Management, 7(3), pp. 12-19.

3. Andreeva Tatiana and Kianto Aino, (2012), "Does knowledge management really matter? Linking knowledge management practices", competitiveness and economic performance, 16(4), pp. 617-636. 
4. Arthur, J. (1994), "Effects of human resource systems on manufacturing performance and turnover", Academy of Management Journal, 37(3), pp. 670-687.

5. Beer, M., B. Spector, P. R. Lawrence, D. Q. Mills, R. E. Walton, (1984) “A Conceptual View of HRM”, In Managing Human Assets. Free Press, New York

6. Bhaskar. Nalla, Dr. P. Varalaxmi, (2014), "Human Resource Management Practices In Organized Retailing - A Study Of Select Retailers", International Journal of Business and Administration Research Review, I (2), pp. 63-74.

7. Bondarouk Tanya, (2016), “Conceptualising the Future of HRM and Technology Research”, International Journal of Human Resource Management, 21, pp. 2579-2671.

8. Brown, M., D. Hyatt, J. Benson, (2010), “Consequences of The Performance Appraisal Experience', Personnel Review, 39(3), pp. 375-396.

9. Chand, M. \& A. Katou, (2007), "The impact of HRM practices on organizational performance in the Indian hotel industry", Employee Relations, 29(6), pp. 576-594.

10. Choi Sang Long, Tan OweeKowang, RajendranMuthuveloo, Teoh Ai Ping, Australian, (2013), “Journal of Basic and Applied Sciences", 7(2), pp. 312-316.

11. Cohen, A. (2003), “Multiple commitments in the workplace. Mahwah, New Jersey”, Lawrence Erlbaum

12. Cunningham, I., (1999), "Human Resource Management in the Voluntary Sector: Challenges And Opportunities", Public Money and Management, 19(2), pp. 19-25.

13. Danvila del Valle, I., A. Castillo, Miguel., Rodrý'guez-Duarte, Antonio, (2009), "The effects of training on performance in service companies”, International Journal of Manpower, 30(4), pp. 393-407.

14. Denby, S., (2010), “The importance of training needs analysis, industrial and commercial training”, 42(3), pp. 147-150.

15. Devanna, M. A., C. J. Fombrun, N. M. Tichy, (1984), “A Framework for strategic human resource management”, Strategic Human Resource Management, New York: John Wiley

16. Dessler, G, (2013), “Human Resource Management. 13th Edition. Pearson Education Limited. Essex, UK.

17. Guest, D. E., (1987), “Human resource management and industrial relations”, Journal of Management Studies, 24, pp. 50321.

18. Edvinsson, L. and Malone, M. (1997), “Intellectual Capital: Realising Your Company's True Value by Finding Its Hidden Brainpower", Harper Collins, 1(2), pp. 87-102.

19. Gardnera Timothy M. and Wright Patrick M., (2009), "Implicit human resource management theory: a potential threat to the internal validity of human resource practice measures", The International Journal of Human Resource Management, 20(1), pp. 57-74.

20. Guest, D., (1997), "Human resource management and performance: A review and research agenda" International Journal of Human Resource Management, 8(3), pp. 263-276.

21. Hassan saria (2016), “Impact of HRM Practices on Employee's Performance”, International Journal of Academic Research in Accounting, Finance and Management Sciences, 6(1), pp. 15-22.

22. Hendry, C. and A. Pettigrew, (1990), “Human resource management: An agenda for 1990's”, International Journal of Human Resource Management, 1(1), pp. 17-44. 
23. Hussain Mansoor and Ahmad Mushtaq, (2012), "Mostly Discussed Research areas in Human Resource Management (HRM) A Literature Review”, International Journal of Economics and Management Sciences, 2(3), pp. 10-17.

24. Iqbal Zafar Muhammad, Irfan Arif Muhammad and Abbas Furrakh, (2011), "HRM Practices in Public and Private Universities of Pakistan”, A Comparative Study, International Education Studies, 4(4), pp. $215-222$.

25. Jafari, M., A. Bourouni, R. H. Amiri, (2009), “A New Framework for Selection of the Best Performance Appraisal Method”, European Journal of Social Sciences, 7(2), pp. 3.

26. Jayawarna, D., A. Wilson, A. Macpherson, (2007), “Training commitment and performance in manufacturing SMEs”, Journal of Small Business and Enterprise Development, 14(2), pp. 321-338.

27. Jeetvikram and sayeeduzzafar, (2014), "A Study of HRM Practices and its Impact on Employees Job Satisfaction in Private Sector Banks: A Case Study of HDFC Bank", International Journal of Advance Research in Computer Science and Management Studies, 2(1), pp. 62-68.

28. Jouda Ali Akram et al, (2016), “The Impact of Human Resource Management Practices on Employees Performance: The Case of Islamic University of Gaza in Palestine”, International Review of Management and Marketing, 6(4), pp. 1080-1088.

29. Kelly, O. K., Y. S. Angela Ang, L. W. Chong, S. W. Hu, (2008), "Teacher appraisal and its outcomes in Singapore primary Schools”, Journal of Educational Administration, 46(1), pp. 39-54.

30. Khan, M. A., (2010), “Effects of Human Resource Management Practices on Organizational Performance - An Empirical Study of Oil and Gas Industry in Pakistan”, European Journal of Economics, Finance and Administrative Sciences, 4(1), pp. $1-10$.

31. Khalid, M. M., Rehman, C. A., Ilyas, M. (2014), "HRM Practices and Employee Performance in Public Sector Organizations in Pakistan: An Empirical study”, International Journal of Management Sciences and Business Research, 3(2), pp. 69.

32. Lynch, S., \& K. Smith., (2010), “The dilemma of judging unpaid workers”, Personnel Review, 39(1), pp. 80-95.

33. Mansour, M., (2010), “Human Resource Practices Impact on Firm Performance: An Empirical Study”, King Fahd University of Petroleum and Minerals., 1(3), pp. 6-34.

34. Munjuri, M. G. (2011), "The effect of human resource management practices in enhancing employee performance in catholic institutions of Higher Learning in Kenya”, International Journal of Business Administration, 2(4), pp. 189.

35. Marques, J., (2007), “HR in all its glory”, Human resource management international Digest., $15(5)$, pp. 6.

36. Meyer, J. P., \& Allen, N. J. (1997), “Commitment in the workplace: theory, research, and application. Thousand Oaks, CA: Sage.

37. Meyer, J. P., \&Herscovitch, L. (2001), “Commitment in the workplace: toward a general model”, Human Resource Management Review, 11(3), pp. 299-326.

38. Meyer, J. P., \& Smith, C. A. (2000), "HRM practices and organizational commitment: test of a mediation model”, Canadian Journal of Administrative Sciences, 17(4), pp. 319-331.

39. Morrow, P. C. (2011), “Managing organizational commitment: insights from longitudinal research”, Journal of Vocational Behavior, 79(1), pp. 18-35.

40. Muhammad Zafar Iqbal, Muhammad Irfan Arif, Furrakh Abbas, (2011), “HRM Practices in Public and Private Universities of Pakistan: A Comparative Study”, International Education Studies, 4(4), pp. 215-222. 
41. Muhammad Maqsood Khalid, Chaudhry Abdul Rehman and Muhammad Ilyas, (2014), "HRM Practices and Employee Performance in Public Sector Organizations in Pakistan: An Empirical study”, International Journal of Management Sciences and Business Research, 3(2), pp. 12-25.

42. Muhammad Naseer Akhtar, SajjadNazir and Muhammad ZohaibIrshad, (2008), "E-Hrm in The New Era-A Comparison Study Between Conventional Hrm and E-Hrm”, pp. 1-19.

43. NongmaithemRobindro Singh, BiniamKassa, (2016), "The Impact of Human Resource Management Practice on Organizational Performance - A Study on DebreBrehan University International Journal of Recent Advances in Organizational Behaviour and Decision Sciences (IJRAOB)”, 1(1), pp. 1-15.

44. Paauwe, J., \&Boselie, P. (2005), "HRM and performance: What next?”, Human Resource Management Journal, 15, pp. 6883.

45. Qureshi M Tahir., \&Ramay Mohammad, (2006), "Impact of Human Resource Management Practices on Organizational Performance in Pakistan”, Muhammad Ali Jinnah University, Islamabad.

46. Qureshi, M., Tahir., Ramay I, Mohammad., Marwat A, Zubair, (2007), "Impact of Human Resource Management (HRM) Practices on Employees Performance”, Muhammad Ali Jinnah University, Islamabad.

47. Ruel, H. J. M., Bondarouk, T. V., \&Velde, M. V. (2007), "The contribution of e-HRM to HRM effectiveness: result from a quantitative study in a Dutch Ministry”, Employee relations, 29(3), pp. 280-291.

48. SangeetaTrehan and Karan Setia, (2014), "Human Resource Management Practices and Organizational Performance”, An Indian Perspective, Global Journal of Finance and Management. 6(8), pp. 789-796.

49. ScheibleCoutoFalcão Alba, VirgílioBittencourt Bastos Antônio, (2013), "An Examination of Human Resource Management Practices", Influence on Organizational Commitment and Entrenchment, BAR, Rio de Janeiro, 1(4), pp. 57-76.

50. Shaheeb Abdul Azeez, (2017), "Human Resource Management Practices and Employee Retention: A Review of Literature", Journal of Economics, Management and Trade, 18(2), pp 1-10.

51. Singh NongmaithemRobindro and KassaBiniam, (2016), "The Impact of Human Resource Management Practice on Organizational Performance - A Study on DebreBrehan University International Journal of Recent Advances in Organizational Behaviour and Decision Sciences”, (IJRAOB) An Online International Research Journal, 1(1), pp. 643-662.

52. Jyothi, P., \& Neelakantan, S. I. T. A. (2013). Quality of Work Life and Acedamic Dual-Career Couples Job Satisfaction. International Journal of Business and General Management, 2(4), 11-20.

53. Singh, K. (2004), "Impact of HR practices on perceived firm performance in India”, Asia Pacific Journal of Human Resources, 42(3), pp. 301-317.

54. Sudin, S., (2004), “Human Resource Practices and Organizational Performance: Review, Synthesis and Research Implication”, International Business Management Conference Paper.

55. Tabiu, A., and Nura, A. A. (2013), “Assessing the effects of human resource management (HRM) practices on employee job performance: A study of UsmanuDanfodiyo University Sokoto”, Journal of Business Studies Quarterly, 5(2), pp. 247-259.

56. Tanveer, Y., M. Z. Shaukat, S. A. Alvi, A. Munir, (2011), "The Way Human Resource Management (HRM) Practices Effect Employees Performance: A Case of Textile Sector", 1(4), pp. 112-117.

57. Tiwari, P., (2012), “Human Resource Management Practices: A Comprehensive Review”, Pakistan Business Review Paper, pp. 669-705. 
58. Terera SR, Ngirande H., (2014), “The impact of rewards on job satisfaction and employee retention”, Mediterranean Journal of Social Sciences, 5(1), pp. 481-487.

59. Tzafrir, S. S., (2005), "The relationship between trust, HRM practices and firm performance”, International Journal of Human Resource Management, 16(9), pp. 1600-22.

60. Ubeda, L., C., \& C. F. Almada Santos, (2007), "Staff development and performance appraisal in a Brazilian research centre", European Journal of Innovation Management, 10(1), pp. 109-125.

61. Waiganjo, E. W., E. Mukulu, \& J. Kahiri, (2012), "Relationship between Strategic Human Resource Management and Firm Performance of Kenya's Corporation Organizations", International Journal of Humanities and Social Science, 2, pp. 10.

62. Whitener, E. M. (2001), "Do "high commitment" human resource practices affect employee commitment? A cross-level analysis using hierarchical linear modelling”, Journal of Management, 27(5), pp. 515-535.

63. Zhang, L. \& Wang, H. (2006), "Intelligent information processing in human resource management: an implementation case in China”, Expert System, 23 (5), pp. 356-369. 
